\title{
Building builders: entrepreneurship education from an ecosystem perspective at MIT
}

\author{
Artur Tavares Vilas Boas Ribeiro ${ }^{1 *}$ D, Juliana Natsumi Uechi ${ }^{2}$ and Guilherme Ary Plonski ${ }^{1}$
}

\author{
* Correspondence: \\ artur.tavr@gmail.com \\ ${ }^{1}$ University of São Paulo, Av. Prof. \\ Luciano Gualberto, 908, \\ NPGT-Butantã, São Paulo, SP \\ 05508-010, Brazil \\ Full list of author information is \\ available at the end of the article
}

\begin{abstract}
This study is about new possibilities on entrepreneurship education. With the emergence of the entrepreneurial universities, academics and university managers started to pay more attention to fostering entrepreneurship among students. However, entrepreneurship education research became more oriented towards teacher activities and neglected the entrepreneurship ecosystem around the university and its role in educating an entrepreneur. This article aims to present new possibilities for entrepreneurship education from this ecosystem perspective. The method was a case study of Massachusetts Institute of Technology, and the results show educational practices that go beyond the classical model of classrooms, involving student-led activities, mentorship programs, competitions, and others. Project-based courses, experience-based activities and active-based activities are well covered in the data presented. In the discussions, we also present a model of organizing entrepreneurship education efforts and compare our results with other research on Swedish entrepreneurial universities. The conclusion reinforces the need to see entrepreneurship education through the lens of ecosystems, highlighting opportunities for future studies.

Keywords: Entrepreneurial universities, University, Entrepreneurship, Entrepreneurial ecosystems, Entrepreneurship education, Education, Innovation, Entrepreneurial culture, Spin-offs, Venture creation, MIT, Massachusetts Institute of Technology
\end{abstract}

\section{摘 要}

这项研究是关于创业教育的新的可能性。随着创业型大学的出现，学者和大学管 理者们开始更加重视培养学生的创业精神。然而,创业教育研究更多地面向教师 的活动,忽视了大学周围的创业生态系统及其对教育一位企业家的作用。本文旨 在从这一生态系统的角度为创业教育提供新的可能性。这个方法是麻省理工学 院的案例研究，结果显示超越了教室的经典模型的教育实践,涉及由学生主导的活 动、导师计划和比赛等。所提供的数据很好地涵盖了基于项目的课程、基于经 验的活动和基于活动的活动。在讨论中，我们还提出了一个组织创业教育的模 式,并将我们的研究成果与其他关于瑞典创业型大学的研究进行比较。所得结论 强化了从生态系统的角度看待创业教育的必要性,突显了未来研究的机会。

关键词: 创业型大学，大学，创业，创业生态系统，创业教育，教育，创新，创业文化， 高技术初创公司, 公司创建, 麻省理工学院 (MIT) 


\section{Résumé}

Cette étude porte sur de nouvelles possibilités en matière d'éducation à l'entrepreneuriat. Avec l'émergence des universités entrepreneuriales, les dirigeants d'université commencent à accorder plus d'attention à la promotion de l'entrepreneuriat par les étudiants. Cependant, la recherche sur l'éducation à l'entrepreneuriat s'est davantage orientée vers les activités des enseignants et a négligé l'écosystème de l'entrepreneuriat autour de l'université et son rôle dans l'éducation de l'entrepreneur. Cet article vise à présenter de nouvelles possibilités pour l'éducation à l'entrepreneuriat dans cette perspective écosystémique. La méthode utilisée consiste en une étude de cas du Massachusetts Institute of Technology et les résultats montrent des pratiques éducatives qui vont au-delà du modèle classique des salles de classe, impliquant des activités dirigées par des étudiants, des programmes de mentorat, des concours et autres. Les cours basés sur des projets, les activités basées sur l'expérience et les activités actives sont bien couvertes par les données présentées. Dans les discussions, nous présentons également un modèle d'organisation des efforts d'éducation à l'entrepreneuriat et comparons nos résultats avec ceux d'études antérieures sur les universités entrepreneuriales suédoises. La conclusion renforce le besoin de voir l'éducation à l'entrepreneuriat à travers le prisme des écosystèmes, soulignant les opportunités pour de futures études.

Mots-clés: universités entrepreneuriales, Université, entrepreneuriat, écosystèmes d'entreprise, éducation à l'entrepreneuriat, éducation, innovation, culture entrepreneuriale, spin-offs, création d'entreprise, MIT, Massachusetts Institute of Technology

\section{Resumo}

Este estudo é sobre novas possibilidades do ensino do empreendedorismo. Com o surgimento das Universidades Empreendedoras, acadêmicos e gestores universitários passaram a dar mais atenção à promoção do empreendedorismo entre os estudantes. No entanto, a pesquisa em educação para o empreendedorismo tornou-se mais orientada para atividades de professores e negligenciou o ecossistema de empreendedorismo em torno da universidade e seu papel na educação de um empreendedor. Este artigo tem como objetivo apresentar novas possibilidades para o ensino de empreendedorismo a partir dessa nova perspectiva. O método foi um Estudo de Caso do Massachusetts Institute of Technology e os resultados mostram práticas educacionais que vão além do modelo clássico de salas de aula, envolvendo atividades lideradas por estudantes, programas de mentoria, competições de negócios e outros. Cursos baseados em projetos, atividades baseadas em experiência e metodologias ativas também são cobertos neste estudo. Nas discussões, apresentamos um modelo para organizar esforços voltados ao ensino de empreendedorismo e comparamos nossos resultados com outras pesquisas sobre universidades empreendedoras suecas. A conclusão reforça a necessidade de ver o ensino do empreendedorismo através das lentes dos ecossistemas, destacando oportunidades para futuros estudos.

Palavras-chave: universidades empreendedoras, universidade, empreendedorismo, ecossistemas empreendedores, educação para o empreendedorismo, Educação, inovação, cultura empreendedora, spin-offs, criação de empreendimentos, MIT, Instituto de Tecnologia de Massachusetts 


\begin{abstract}
Аннотация
Настоящее исследование посвящено новым возможностям в сфере предпринимательского образования. С появлением предпринимательских университетов, сотрудники академий и институтов стали уделять более пристальное внимание развитию навыков предпринимательства среди студентов. Тем не менее, исследования в сфере предпринимательского образования оказались в большей степени ориентированы на преподавательскую деятельность, упустив из виду предпринимательскую экосистему университета и ее роль в обучении предпринимателя. В данной статье изучены новые возможности предпринимательского образования с позиций экосистемы. В работе использован пример Массачусеттского Технологического Института, который представляет образовательные программы, отличающиеся от тех, которые традиционно преподаются в стенах учебных кабинетов, и включают координируемые студентами проекты, менторство, конкурсы и прочее. В подобные курсы включены практические занятия, проектная и самостоятельная работа. В обсуждении мы также представили модель предпринимательского обручения в организациях и сравнили с результатами другого нашего исследования, посвященного предпринимательским университетам в Швеции. В заключении сделан вывод о необходимости поддержки предпринимательского образования с учетом окружающей экосистемы, что будет представлено в дальнейших исследованиях.
\end{abstract}

Ключевые слова: предпринимательские университеты, предпринимательство, предпринимательская экосистема, предпринимательское образование, инновации, предпринимательская культура, спин-офф, создание совместных предприятий, МІT, Массачусеттский технологический институт

\title{
Resumen
}

Este estudio trata de nuevas posibilidades en educación empresarial. Académicos y administradores universitarios han comenzado a prestar más atención al fomento del espíritu empresarial entre los estudiantes. Sin embargo, la investigación en educación empresarial se orientó más hacia las actividades docentes y descuidó el ecosistema de emprendimiento en torno a la universidad y su papel en la educación del emprendedor. Este artículo tiene como objetivo presentar nuevas posibilidades para la educación empresarial desde una perspectiva del ecosistema de innovación. Estudiamos el Instituto de Tecnología de Massachusetts (MIT) y observamos prácticas educativas que van más allá del modelo clásico de aulas, y que incluyen actividades dirigidas por estudiantes, programas de mentoría, competencias y otros. Observamos también el contenido de cursos basados en proyectos, las actividades basadas en la experiencia y práctica. También presentamos un modelo de organización de esfuerzos de educación empresarial y comparamos nuestros resultados con otras investigaciones sobre universidades empresariales suecas. Nuestra conclusión es que el enfoque de ecosistemas es superior para la educación empresarial.

Palabras clave: universidades emprendedoras, Universidad, emprendimiento, ecosistemas emprendedores, educación empresarial, educación, innovación, cultura emprendedora, spin-offs, creación de empresas, MIT 


\section{Multilingual abstract}

Please see Additional file 1 for translation of the abstract into Arabic.

\section{Introduction}

Starring the public policies of countries and specific regions, entrepreneurship has become an important agenda due to its direct relationship with economic development and national prosperity (Lerner 2010; Acs and Amorós 2008). Entrepreneurship and innovation, as also pointed out by the classics (Schumpeter 1942; Drucker 1985), lead to job generation, industry reinvention, efficiency gains, regional competitiveness, and other aspects. This argument reinforced the need for policymakers thinking holistically, especially about the role of a complex set of agents in creating a vibrant region towards the development of new, and more innovative, businesses.

Among many of these actors involved in entrepreneurial ecosystems-such as government agencies, corporations, funding bodies, and cultural factors-universities are highlighted due to its role in the increased intensity of knowledge involved in innovative businesses (Etzkowitz and Leydesdorff 2000). According to Etzkowitz (2013), much has evolved in (i) support mechanisms to venture creation (with the advent of new practices and processes), (ii) the role of the university and its relationship with knowledge spillover (with programs more permeable to the demands of the industry and new organisms encouraging innovation within the academic walls), and (iii) the willingness and involvement of students and teachers in the creation of new businesses. Despite this, some scholars point out that current research has paid little attention to entrepreneurship education and the development of the entrepreneurial student (Hayter et al. 2017).

Today, a university seeking a more entrepreneurial orientation through entrepreneurship education will find research either in highly cited papers with a limited focus on the role of professors or in different pedagogical approaches with little uniformity or consistency (Rasmussen and Sørheim 2006). Examples can be found in excerpts from seminal articles on entrepreneurship education, such as Kuratko's (2005) analysis on the emergence of entrepreneurship education, with its conclusions being an educator-centered call to action.

In this case, the emergence of the entrepreneurial university brings with it new possibilities for entrepreneurship education. No longer limited to classrooms, the spaces of entrepreneurship education have expanded to laboratories, experiential activities, mentoring networks, and other ecosystem players. As pointed out by Etzkowitz (2013), many universities may be neglecting their possibilities of supporting entrepreneurship and having functions being replaced by transformative grassroots movements from its own ecosystem. What we seek with this study is to present entrepreneurship education in an ecosystem perspective-considering that entrepreneurship can be taught beyond the classroom and viewing the entrepreneurial university as an agent that offers several possibilities in this regard. Understanding that the Massachusetts Institute of Technology (MIT) was a good model of engaging the ecosystem around fostering entrepreneurship among students (O'Shea et al. 2007), we saw the opportunity of doing a research around this university model. Therefore, the main research question orienting the study is "how can MIT's entrepreneurial university model contribute to current research in entrepreneurship education?" 
Thus, we set forward a case study about the way that the Massachusetts Institute of Technology is developing its entrepreneurship education activities. Data were collected through an immersion at MIT's ecosystem, involving 17 in-depth interviews, secondary data, and photographic records. The next sections will be as follows: the second section with the theoretical foundations for our research, the third section presenting the methods that we used, the fourth and fifth section to present our results and discussions on it, and the sixth section will give readers the final conclusions.

\section{Theoretical framework}

\section{The emergence of the entrepreneurial universities}

Having its foundations on the shoulders of giants such as Schumpeter (1942) and Drucker (1985) and advancing to more recent authors such as Acs et al. (2008), Lerner (2010), Aparicio et al. (2016) and Isenberg (2010), the premise that entrepreneurship positively revolutionizes economies is sustained. However, this understanding is not enough and brings with it other questions: how to stimulate entrepreneurship for regional development? Which agents are involved and how do they go about it? What are the best practices and main mistakes? These questions have been worked on in the literature, and, nowadays, a good body of research can already be found bringing reflections for each topic (Fritsch 2008). But other questions still have a broad range of discussion, especially when deepening the role of universities in entrepreneurship ecosystems. This moment in the current research is well covered by the work of Guerrero et al. (2016a, 2016b).

Following the development and advancement of higher education institutions, it is possible to see universities maturing their missions and developing arms with more entrepreneurial orientations-what has been called the emergence of the entrepreneurial university model (Etzkowitz and Leydesdorff 2000; Steffensen et al. 2000; Rothaermel et al. 2007).

By definition, an entrepreneurial university "provides an adequate environment for the university community that serves as a conduit for entrepreneurial initiatives that will contribute to long-term economic and social development through its multiple missions" (Guerrero et al. 2016a, p. 106). To dissect the research around the entrepreneurial universities, O'Shea et al. (2007) presents four perspectives commonly used in academic works:

(i) Studies that emphasize the role of individuals (personality, motivation, entrepreneurial behavior, etc.) in the business creation;

(ii) Studies rooted in the social sciences highlighting the impact of the environment on the emergence of companies, dealing with points such as university infrastructure, the research quality, and resources availability;

(iii) Studies focused on cultural aspects and social norms, which points to the aspects related to entrepreneurial mindset and the impact of behavioral consensus-the development of a common thinking among peers due to an alignment of the selection of new scholars and the dissemination of this mindset through socialization;

(iv) Studies exploring the impact of wider forces, such as the economy, regional elements, and local legislation. 
It is important to notice that the four perspectives are not mutually exclusive. On the contrary, they are just the result of a big picture-with complex relationships that are commonplace in social studies.

On the role of universities in entrepreneurship education, Rasmussen and Wright (2015) point to three individual competencies that can be fostered by higher education institutions: (i) opportunity development competency, being the ability to recognize and exploit opportunities in scientific research; (ii) championing competency, being the ability to develop a business vision and convince others to contribute; and (iii) resource acquisition competency, being the ability to organize resources in the exploration of opportunities. For the authors, this competence building can occur in several levels and organizations, such as central university management, technology transfer office, laboratories, and student/alumni bodies. This diverse set of agents involved brought another concept around the emergence of entrepreneurial universities: the university-based entrepreneurial ecosystems (Fetters et al. 2010).

The role of independent organizations in the university ecosystem, such as student-led groups and entrepreneurship centers, has been prominent in recent research, especially in debates about the power of autonomous movements in changing universities (Clark 2004). Examples are becoming well recognized, such as the StartX case in Stanford (Etzkowitz 2013) or entrepreneurship centers at the International Institute of Information Technology, at the Utrecht University, and at MIT (Jansen et al. 2015). This attention to the ecosystem of an entrepreneurial university leads us to the search of the present study: to better understand the educational roles performed by these various agents of an entrepreneurial university ecosystem.

Although there is a good body of recent studies on the contribution of universities on entrepreneurship ecosystems (Guerrero and Urbano 2012, 2014; Jansen et al. 2015; Rasmussen and Wright 2015), we understand that this quest around entrepreneurship education in an ecosystem perspective could be better explored. For example, Hayter et al. (2017) brought attention to the lack of studies focused on the relationship between entrepreneurship and individuals at universities and developed their studies for the Journal of Technology Transfer around the role of graduate students on academic entrepreneurship.

\section{Entrepreneurship education from an ecosystem perspective}

For more than a decade, the "can entrepreneurship be taught?" debate has come to an end with studies showing that, yes, entrepreneurship can be taught (Kuratko 2005; Gorman et al. 1997). This reinforces the message written by Peter Drucker apud Kurato (2005, p.580): “The entrepreneurial mystique? It's not magic, it's not mysterious, and it has nothing to do with the genes. It's a discipline. And, like any discipline, it can be learned." The main premise behind the argument that entrepreneurship could not be taught was a misunderstanding about educational concepts.

In this misunderstanding, the image around education was limited to teaching into the classical model of classrooms: one teacher in front of a classroom using lectures and readings to teach concepts and theories. Naturally, this could not cover behavioral and other important aspects of an entrepreneur's self-efficacy, such as resilience and marketing skills. Nowadays, the most cited studies on entrepreneurship education are 
still focused on the classic teaching model, bringing to the professor the responsibility of the student's behavioral modification process (Heinonen and Poikkijoki 2006; Kuratko 2005; Katz 2003; Gorman et al. 1997).

On the basis of learning studies, we will find definitions such as Boyd and Apps' (1980), who argue that learning is a process of behavior modification through the acquisition or alteration of knowledge, skills, and attitudes. Another well-established educational framework can be used: as highlighted on the Encyclopedia of Curriculum Studies (Kridel, 2010), Coll's taxonomy (Coll and Edwards 1997) proposes that a student can have conceptual, procedural, and attitudinal learning outcomes. Reinforcing this point of view, the seminal article of Kraiger et al. (1993) brings an educational framework that divides learning into cognitive, skill-based, and affective outcomes. Using these frameworks to analyze entrepreneurship education, it becomes easier to understand that the classical view of teaching only covers a minor aspect of entrepreneurial competencies, the knowledge/cognitive aspect, usually ignoring skill-based and attitudinal aspects. The question that lies here is "what can be done for educating entrepreneurs beyond the classical model of teaching?” Some authors have sought to bring good answers.

Pointing to beyond the classroom model, studies have stressed new ways of teaching entrepreneurship, such as student learning from concrete university experiences or even creating a company and learning along the way (Sullivan 2000; Rasmussen and Sørheim 2006; Kolb and Kolb 2009). Politis (2005), influenced by Kolb's (1984) experience-based learning approach, proposes a framework in which the entrepreneur goes through concrete experiences, which usually happens beyond the classroom walls, and learns after reflecting on it. Seeking to overcome the distance between the classroom and the practice-based learning, Neck and Greene (2011) built a pedagogical portfolio oriented to the construction of activities for reflective practice-ranging from simulations and games to the creation of real companies. Proposing a broader framework, some authors have recently made use of Triple Helix framework to build upon (Mandrup and Jensen 2017; Blenker et al. 2006).

For Klofsten (2000), the entrepreneurship education in an entrepreneurial university is based on three pillars: (i) the existence of an enterprising culture that permeates the students' universe in order to awake greater motivation around the subject; (ii) courses with specific entrepreneurship contents, such as financing, legal environment, and others; and (iii) training programs focused on individuals who want to set up their own business. The model dialogs with the proposals of St-Jean and Audet (2009), which places the learning of the entrepreneur supported by three ways: the affective, relative to values and motivations; the cognitive one that works with formal concepts and knowledge organization; and the skill-based, more related to the technical mastery.

All of these studies carry the understanding that entrepreneurship education needs to undergo more practical activities, through a learning-by-doing process, especially in the development of competencies such as teamwork, resilience, and creativity.

At this point, we can connect the ecosystem perspective on our theoretical framework. Integrating other elements of a university, Rasmussen and Sørheim (2006) present the role of diverse organizations in the building of a comprehensive educational structure for entrepreneurs on Swedish universities. For the authors, organizations such as Entrepreneurship Centers, Innovation Laboratories, Entrepreneurship Programs, and 
specific schools can build what they call active learning, with the entrepreneur coming out of passive learning models (e.g., case-based learning or traditional classes) and immersing in active-learning processes (e.g., creation of a real company). For this kind of real-life learning through a new business creation, some authors reinforce the role of mentorship in fostering personalized learning processes with specific guidance and emotional support (St-Jean and Audet 2009; Deakins et al. 1998).

The advancements on entrepreneurship education theory point to a clear transition: (i) students learning inside classrooms according to the teacher pedagogical choices; (ii) students learning through practical experiences and their own reflections on the process; and (iii) students learning with real-life venture creation followed by mentor guidance. Although they are different approaches, we understand that they are not mutually exclusive. The best practices seem to live in the intersections with complementary institutional arrangements in the entrepreneurial university (Rasmussen and Sørheim 2006).

It is important to notice that, when it comes about learning, it is common that an educational approach does not cover the role range of competencies of an entrepreneur. For example, a project-based classroom that focuses on learning mechanics concepts through the building of a little car is expected to educate a future entrepreneur on technical knowledge and tools mastering. In the same way, Kraiger et al. (1993) and St-Jean and Audet (2009) highlight that the development of technical skills does not occur so intensely on mentor-driven education. The theory thus shows that this horizon of different educational approaches should be designed in a complementary way, seeking to cover the whole set of entrepreneurial competencies with a comprehensive structure in mind.

This need for complementarity reinforces Rasmussen and Sørheim's (2006) arguments: "there are little uniformity and considerable diversity regarding objectives, philosophy, content, pedagogy, and outcomes" on entrepreneurship education. In this context, we saw that the model of MIT's entrepreneurship education could be an opportunity to find greater clarity regarding good practices. This led us to the research question that permeates the present study-how can MIT's entrepreneurial university model contribute to current research in entrepreneurship education?

\section{Research orientation and methods}

With the current research leading us to the research question around entrepreneurship education at MIT, we sought to delineate a focused primary objective: to analyze new possibilities for entrepreneurship education with data collected through interviews and other records at MIT's ecosystem.

The study was a case study research (Eisenhardt 1989) realized in an immersion at the Institute, and data collection was conducted through in-depth interviews complemented with photographic records, institutional documents analysis, and non-participant observation. It was sought to conduct 17 interviews with those responsible for MIT's organizations or at least members who had an understanding of the location activities, processes, and history. To provide greater consistency in the production of the study, some scientific premises were followed based on Eisenhardt's proposals:

- Multiple investigators: two researchers, from different fields of knowledge, participated in the research, in order to bring complementary visions and reduce individual biases. 
- Multiple data collection methods: In addition to the central method of data collection, in-depth interviews, the present study relied on non-participant observation of MIT environments and photographic records, as well as primary and secondary information present in institutional materials of the visited environments.

- Data overlapping: the joint collection of data generating an overlapping is one of the points advocated as important in creating information consistency. For this article, overlapping was sought through field notes, interview transcription, and written sources of knowledge.

Data analysis was done using Stake's assumptions (Stake 1978) oriented to allow the descriptive depth presented in the case to bring the absorption as a product of the reader's own experience in navigating the study, as he points out:

"What becomes useful understanding is a full and thorough knowledge of the particular, recognizing it also in new and foreign contexts. That knowledge is a form of generalization too, not scientific induction but naturalistic generalization, arrived at by recognizing the similarities of objects and issues in and out of context and by sensing the natural covariations of happenings." (Stake 1978, p. 6)

\section{Results: the case study on entrepreneurship education at MIT}

Understanding that relevant publications have already been produced specifically on the entrepreneurship phenomenon at the Massachusetts Institute of Technology, we could not fail to open the case study with those publications.

Etzkowitz (2003), in his book "MIT and the Rise of Entrepreneurial Science," describes the historical process of building MIT as a scientific and entrepreneurial role model. Briefly, this historical process can be read in the following stages: (i) the idealization of the Institute and its applicability-oriented mission, being a land grant university model, and its debates heading to an industry permeable modus operandi (the controversy surrounding the consulting activities practiced by teachers being one of the best representations of this); (ii) the intensification of research activities and the relevance growth of MIT at World War periods-highlighting the Institute's ability to respond to governmental demands with agility and to organize strong resources for effective technological development; and (iii) finding the commercial value of research, unfolding into the creation of regulations, institutional actors, good practices, and the emergence of corporations, spin offs, and the New England entrepreneurial ecosystem in general. The book highlights one of the positions of MIT's founder, William Barton Rogers, in his period of idealization of the Institute:

"In a carefully thought out charter document written in 1846, Rogers wrote that:

'There is no branch of practical industry, whether in the arts of construction, manufactures or agriculture, which is not capable of being better practiced, and even of being improved in its processes through the knowledge of its connections with physical truths and laws and therefore we would add that there is no class of operatives to whom the teaching of science may not become of direct and substantial utility and material usefulness." (Etzkowitz 2003, p. 21) 
Other studies have been developed around understanding MIT's ecosystem, some with more attention to the historical process and the evolution of MIT numbers (Roberts et al. 2015; Roberts and Eesley 2011), while others sought to dissect the practices of the Institute to better understand the agents involved and good practices in general (O'Shea et al. 2007; Lüthje and Franke 2002; Jansen et al. 2015). For O'Shea et al. (2007), eight factors underlie MIT's success in venture creation: (i) science and engineering resource base, (ii) industry funding of research, (iii) quality of faculty, (iv) organizational characteristics, (v) university mission, (vi) faculty culture, (vii) history and tradition, and (viii) MIT's location. More recently, Hayter et al. (2017) proposed an analysis on the role of graduate students in the development of MIT's spinoffs, and their assessment about the lack of studies on entrepreneurship education led us to build this article.

\section{Data analysis on entrepreneurship education at MIT}

Our research immersion was aimed to understand the MIT entrepreneurship ecosystem, especially the way that programs and services are designed to foster entrepreneurship education inside the campus. With the data collected, we saw an interesting pattern on entrepreneurship education: a set of efforts that are being made to build a "builder mindset" in students. In this builder mindset, we have entrepreneurial competencies, science, and engineering knowledge, a culture of discovery and experimentation and a solid foundation of work ethics. We then separate our data in three main educational unfoldings: classrooms, complementary activities, and real-life entrepreneurship support. The topics below present a deepening of the data.

\section{Project-oriented classes and the role of MIT's professors}

Although much has been said that entrepreneurship cannot be taught in classrooms, some important aspects of training an innovative and entrepreneurial MIT student happens "inside" classrooms (that expands to the whole campus and beyond). The big difference lies in the way that technological entrepreneurship competencies are built. In our research, we realize that the Institute has been a pioneer in building project-oriented classes that stimulate teamwork, mastering advanced tools, and systemic thinking in product building or organizational development.

The role of teachers demonstrated to be very important in this innovative approach at MIT classes. Generally speaking, the interviewees emphasized this project-based approach to education-usually with classes that are very oriented to building things and with a large volume of activities held in laboratories and workshops. In both undergraduate and graduate disciplines, there is also a cultural element to be highlighted: the involvement and passion of teachers in building things, reinforcing the motto of hands and minds working together (mens et manus). For an in-depth analysis, some of the courses cited in interviews received more attention, with information also collected from institutional materials. The most emphasized in interviews are explored below.

- How To Make (almost) Anything (MAS.863): This course is one of the most coveted at MIT due to its "free and fun" hands-on approach. Students here can develop their own projects without any judgment of commercial viability or market 
desirability. For these projects, digital manufacturing concepts are introduced to students, which include the use of rapid prototyping tools, equipment, and machines such as 3D printers, laser cutters, and milling cutters. During the semester, students also have to build a website to register the project development notes and lessons learned.

- How to Make Something that Makes (almost) Anything (MAS.S62): This course aims to show students that they can build their own machines that are capable to build what they need. Throughout the course, the students also develop a machine project, and most parts of the activities are held at MIT's fab labs and workshops.

- Product Engineering Process (2.009): Students form large teams to solve a problem and receive all necessary support and resources (including $\$ 5000$ for materials, a team of instructors, and access to laboratories) to construct a technological product that will be presented at the end of the semester at a grand event for an audience of more than a thousand people and online broadcasting. Despite the high workload and difficulty level of the course, it stands out among the students as a fun course. During the semester, various competitions are held in and outside the classroom, ranging from dismantling a product to create a panel of components and their suppliers to immerse themselves in another reality with garden-set scenarios to build a vehicle. Being a comprehensive class, students learn prototyping, physical construction, project management, communication, and design.

- Tangible interfaces (MAS.834): Course content explores man-machine interaction and discussion of materials engineering. During the first hour of class, the teacher brings a special guest who, in addition to publicizing their projects in the area, explains where their motivations came from and the ideas for these projects. According to one interviewee, these contents collaborate showing to students that it is possible to find other applications for the same technology or showing that failures are part of the process of being innovative.

- New enterprises (15.3901): Aims to educate the student as an entrepreneur through practical activities such as "Take an Entrepreneur to Dinner" where students need to access and interview an entrepreneur and develop a business model. Its content follows the steps of MIT's Professor Bill Aulet book-“The Disciplined Entrepreneurship" (Aulet 2013).

- Science Fiction to Science Fabrication (MAS S95): This course explores creativity through science fiction films and books. For example, students need to watch Star Wars and find specific insights about technologies from that universe, predicting potential problems caused by such technologies-and its reflections should be supported by real data. The course was presented as a great exercise of critical and innovative thinking.

- Start MIT: A 2-week course offered during the independent activity period of January in which students are introduced to the Boston and Cambridge entrepreneurship ecosystem and also to programs and opportunities offered by MIT. In addition, it contains inspirational activities such as lectures and talks with entrepreneurs and hands-on activities where students work on their own projects with mentorship support. 
In this sense, we have conceptual learning through reading materials, lectures and project research, and a lot of instrumental learning using machines or creating new technologies. Other competencies, such as resilience, focus, creativity, problem solving, and teamwork also showed up very frequently in our data.

\section{Experience-based learning through individual exploration}

Since the proposal of experience-based learning is behavior change that happens when the student goes through some kind of concrete experience and reflects on the conflicts generated by it (Kolb 1984), it is important to note the role of complementary activities in the education of an MIT student. An important premise of the Institute is that the student discovers itself through the experimentation of several activities, giving him autonomy in the choice of their experiences. One thing to note is the institution's policy of "pass or no record" in freshman year. Aiming at the process of autonomous discovery, first-year students can enroll in a variety of courses and activities-and if the consequences of poor choices result in failed grades, this does not appear in his academic record or affects his GPA. The positive impact of this policy has already been presented in another study discussing innovation training (Newman and Amir 2001).

As a result of fostering student autonomy and supporting entrepreneurship movements, several organisms came to life on campus. The university atmosphere is rich with experience-based learning opportunities such as:

- Student-led clubs: organization of robotics competitions, entrepreneurship clubs, community support groups, student performance groups, and a host of other groups in which students can engage. These opportunities, by having a strong emphasis on self- management skills, not only offer expertise related to the group, but also skills related to leadership, team management, finance, and other management-related skills. These are grassroots movements and are said to have a great impact on the entrepreneurial orientation of the Institute.

- Events: hackathons, conferences, lectures, business plan competitions, seminars, open lecture programs, open classes, and others are all composing the vibrant atmosphere within MIT. According to the interviews, every week there is a different event with a different theme, usually involving interesting people (leaders of big technology companies) and good sponsors-which is also interesting for professional networking.

- Research projects: in addition to the student activities and events, the broad scope of the research projects was highlighted. As a result of the quality and volume of research conducted by MIT, the opportunity to work with any topic that interests you-usually in departments that are at the frontier of research on the subject-is also considered a key aspect of the students' complementary development.

One of the important aspects of these opportunities is that the student is engaging in activities that he enjoys. It is common to hear that all are busy with several projects, but most of these projects are not related to the formal activities of graduation but rather to parallel activities related to such complementary experiences. The fun involved in such activities, which also often carry high technical demand, is one of the strongest cultural traits perceived in MIT. ${ }^{1}$ 
In addition, the high-pressure conditions of the compromises assumed by the students (with complementary activities and the high formal requirement in MIT classes) seem to stimulate a sense of community and collaboration among students, which, for one interviewer, was a decisive factor for the choice of the Institute in relation to Ivy League universities. Another example of how this learning through discovery is important at the Institute was found on the motto of MIT's Media Lab, one of the University's most highlighted innovative spaces:

“The Media Lab focuses on 'uniqueness, impact and magic'. What our students and faculty do should be unique. We shouldn't be doing something that someone else is doing. If someone else starts doing it, we should stop. Everything we do should have impact. Lastly, things should induce us to be passionate and should go beyond incremental thinking. 'Magic' means that we take on projects that inspire us. In the Lifelong Kindergarten group, researchers often describe the 'Four Ps of Creative Learning' as Projects, Peers, Passion and Play. Play is extremely important for creative learning. There is a great deal of research showing that rewards and pressure can motivate people to 'produce', but creative learning and thinking requires the 'space' that play creates. Pressure and rewards can often diminish that space, and thus, squash creative thinking." (Ito 2014)

This discover-focused environment leads to profound experiences that create the learning presented on the experience-based learning theory. In this approach, we found a greater emphasis on attitudinal development due to the autonomous and self-led characteristics of the activities, as well as more instrumental skills development on more technology-driven activities. Students here learn mostly from peers, also learning through personal reflection and specific materials that they discover by themselves.

\section{Active learning building real-life business}

A third way of entrepreneurship education at MIT is active learning. In this modality, there is the creation of a real company, and the learning takes place through trial and error, reflection, and feedback loops. While some point out that this is the only way entrepreneurship is taught-and that there is no support mechanism that can help, some studies already refute such skepticism (see the "Introduction" section), and our research complements this refutation. In the context of active learning, some content can help entrepreneurs in moments of reflection but more importantly is the role of mentorship in the construction of the business.

Being able to be summarized with a highlighted phrase in one of the interviews-"I can build whatever I want, whenever I want"-the availability of resources and programs for the creative exploration of students is central to the phenomenon studied. In addition to the various places to build things (MIT has 28 marker spaces and workshops in more than $11,148 \mathrm{~m}^{2}$ ), the university has a number of organizations supporting entrepreneurship and innovation. These are mechanisms such as the Venture Mentoring Service, Martin Trust Center, and others cited above that give the student greater focus on the central aspects of their startup without worrying about unnecessary bureaucracies or complexities. In these spaces, students can as well access mentors, funding, awards, and business development processes. 
Some characteristics of these facilities and spaces were punctuated in the interviews, such as (i) access to laboratories of partner companies, which allows greater access to resources (physical and human) and contact with the demands of the industry; (ii) departmental multidisciplinarity, such as the Stata Center, which involves departments and laboratories in both computer science and linguistics and philosophy; and (iii) formal and informal networks, involving wide access to mentors by official programs, as well as key contacts in informal venues. ${ }^{2}$

The special role of mentors has been highlighted at various times as one of the great elements of MIT's ecosystem. The Institute is distinguished by its high-level alumni network but also presents unique models in the way of addressing mentoring processes. The first aspect is the differentiation that some programs work on support figures: (i) the role of the mentor, a person who has experience and establishes a voluntary long-term commitment to the program; (ii) the role of the fellow, being a direct support agent who acts as a coach in the development of teams, centered on the process and program guidance; and (iii) the role of the specialists, usually someone in the industry with specific expertise who assists in a specific demand but without a long-term commitment to the teams-their participation being limited to one-on-one visits, office hours, or even video conferencing meetings. We highlight that one of the most cited MIT ecosystem agents in the interviews was the MIT Venture Mentoring Service.

In models such as the Deshpande Center and the Sandbox program, we saw an active participation of specialized consultants such as lawyers, technical experts, industry people, or MIT Technology Licensing Office agents for specific guidance on the feasibility of intellectual property. In the case of the Martin Trust Center, "Resident Entrepreneurs" are responsible for supporting students with ideas at an embryonic stage, being a way to return the support received in the past. The "give back" feeling of the network of trainers is the central factor in the engagement of all these agents, and they actively participate in the ecosystem, often considered an important success factor of some MIT startups. The power of this MIT mentorship ecosystem can be seen in this excerpt from a story of a successful alumni company:

"Now PlenOptika is focused on ramping up production for its primary and secondary markets. But Dave notes MIT's entrepreneurial ecosystem was key in helping launch the startup six years ago. The team, then called IOVista, started thinking seriously about commercializing the technology after winning the Segal Family Emerging Markets track prize in the 2012 MIT \$100K Entrepreneurship Competition. MIT's Venture Mentoring Service was especially valuable in offering sage advice on founding a company, iterating business models, fleshing out contracts, and fundraising, as well as connecting with potential partners, Dave says. In fact, Dave still reaches out to the VMS mentors for business and personal advice. 'They've mentored us on everything,' Dave says. 'I can't say enough good things about the VMS."' (Matheson 2018)

For active learning at MIT, the education seems to happen with feedback loops from mentors' advice and processes guidance. Specifically on support processes, the use of Disciplined Entrepreneur (Aulet 2013), created by an MIT professor and currently used 
around the world, has been widely used. Mentors educate entrepreneurs sharing concepts through personal experience, as well as shaping behaviors being role models or with specific advice about effective attitudes. In a very technical environment such as MIT, this kind of guidance prove to be very powerful, especially for scientists to learn more about business knowledge, such as marketing strategy, business planning, fundraising, and intellectual property.

\section{Discussion}

Regarding how to teach entrepreneurship, the current research has presented new educational approaches often putting them at the expense of methods considered as outdated (e.g., classroom learning versus active-based learning). In this sense, the new educational methods are being proposed in a substitutive way, and, in our research, we found out that they should not be treated in a mutually exclusive way, but in a complementary way. With this in hand, teachers, university managers, and policy-makers should pay more attention to how the ecosystem of the university can help in fostering students' knowledge, skills, and attitudes towards entrepreneurship.

For this complementarity, we organized the activities around entrepreneurship education concepts that were presented in the theoretical framework, dividing them into four pillars: conceptual outcomes, procedural outcomes, attitudinal outcomes, and enterprising culture. The elements are built upon education theory frameworks (Coll and Edwards 1997; Kraiger et al. 1993) together with entrepreneurship education frameworks (St-Jean and Audet 2009; Deakins et al. 1998; Rasmussen and Sørheim 2006).

One finding of the present study was an aspect that educational theory frameworks did not cover when it comes about entrepreneurial universities: the enterprising culture permeating the whole university that was pointed out by Klofsten (2000). Our data from MIT reinforces Klofsten's element. It became clear that the MIT motto (mens et manus) reflects on the faculty openness to innovation and the great set of activities, creating a strong element on students' motivations and engagement on entrepreneurship education. Because of that, we incorporate the enterprising culture in our model but in a way that permeates the three outcomes, offering a vibrant atmosphere towards entrepreneurship.

The ecosystem perspective helps to organize the four pillars of our model, resonating the studies on entrepreneurship education of our theoretical framework (Guerrero and Urbano 2012; Guerrero and Urbano 2014; Jansen et al. 2015; Rasmussen and Wright 2015; Hayter et al. (2017). In practice, ecosystem agents can use these studies to explore their activities and build comprehensive efforts on entrepreneurship education. We understand that this convergence also gives more reliability in our findings.

To have a deep analysis and test our four pillars, we also create a comparison between our findings of practices at MIT and the findings at Swedish Universities presented on the Rasmussen and Sørheim study (Rasmussen and Sørheim 2006). We brought three important ecosystem agents that showed in the three topics of our data and compared with three different examples presented in the Rasmussen and Sørheim study (Table 1).

Furthermore, the present study sought a thorough analysis of three core entrepreneurship education practices: classroom education, complementary activities education, and entrepreneurship programs education. For classroom practices, our findings are in 


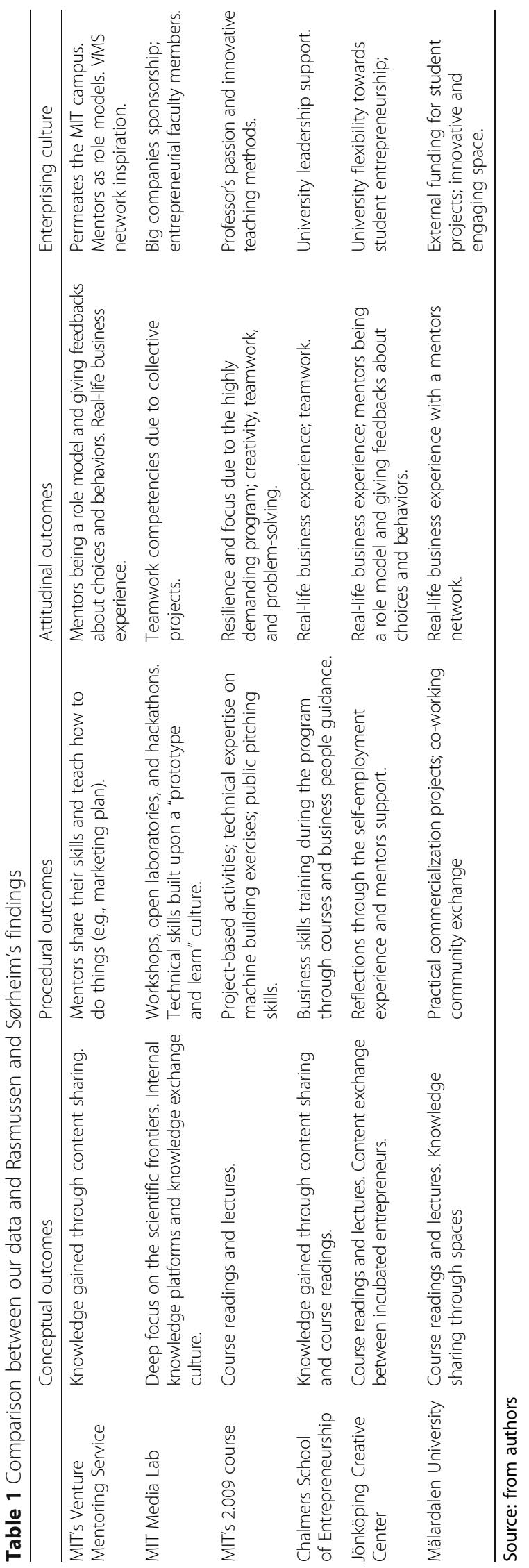


line with the current research: project-based or experience-based courses are better suited for entrepreneurship education due to the practical orientation (Heinonen and Poikkijoki 2006; Politis 2005; Neck and Greene 2011). With the advent of new technologies for rapid prototyping (3D printers, laser cutting, and others), the possibilities of technical projects gain other horizons and really impacted the way that project-based courses are offered at MIT.

When it comes about complementary activities education, less attention is being given by the current research. As Etzkowitz (2013) points out, student-led efforts can play an important role inside the university's entrepreneurial aspirations. In this section, we sought to show how the experimentation and freedom of choice given to MIT students impact their engagement in different activities that led to entrepreneurship education. This kind of personal experience, such as the management of a student club, participating in robot competitions, and working with technologies in specific groups was pointed out in a number of interviews as the main responsible for entrepreneurial competence building. For this, Blenker et al. (2008) argue that universities should evolve the pedagogical approach from teaching (professor-pupils) to learning (experiences-students). Although the main emphasis of current research on professors leading the experience-based educational efforts, we saw that MIT's student community handles it in a variety of formats that may be the best way to achieve personalization for different students' interests.

On the third educational practice, entrepreneurship programs, the pedagogical mediation becomes a mentorship duty. We still have not found too much detailed research on mentorship structures, only studies such as those from Klofsten (2000), Sullivan (2000) and St-Jean and Audet (2009) that explain the role of mentors on entrepreneurial learning. In our study, specific elements showed up-the importance of group mentorship, strict meeting rules, and clarity on commitments and expectations. MIT's approach with the VMS program is based on a "no strings attached" model that the entrepreneurs set the pace of the evolution, while in other programs, such as Sandbox Program, there is a strong process orientation and milestone-based follow-up. With this, the current research questions such as "loose models" versus "tied models" still remains and seems to be an opportunity for future research.

\section{Conclusions}

With our study, we aimed to support in two underdeveloped discussions that we saw on current research on entrepreneurial universities: lack of uniformity on entrepreneurship education practices and an excessive attention on the role of professors in leading educational efforts. We understand that entrepreneurial universities must be viewed from an ecosystem perspective, as many authors highlight, and, thus, entrepreneurship educational practices should follow the same path.

Therefore, university leaders of an aspiring entrepreneurial university should also think about their educational practices in a comprehensive way and understand that entrepreneurship education cannot take place exclusively inside classrooms. Entrepreneurship education, as we saw in this MIT case, should take place in the university as a whole-with project-based courses, student autonomous initiatives, real venture creation supported by mentorship networks and so on. We hope that, with our model resulting from the case study, scholars and university managers can find a better uniformity and clarity around activities to foster entrepreneurship education. 
The answers to our research questions-how can MIT's entrepreneurial university model contribute to current research in entrepreneurship education?-are clearer now, but quantitative studies measuring impacts and comparing the best practices would be important to establish our advancements in a solid ground. One suggestion for future research is an in-depth analysis of the main disciplines identified, seeking to understand each activity and their pedagogical approaches, as well as their results and student perceptions. Another perceived research possibility was the engagement of a considerable number of students and professors in the social media platform Quora, with a large number of answers talking about the experience and the education at MIT. Although this has not been a data source used, it is believed that a study using content analysis on the large volume of data of that platform can bring consistent insights if well developed.

Finally, it should be noted that the research has some limitations that must be addressed and in the future complemented by other works. The first of these is related to the nature of the study-exploratory, based mainly on interviews-which may offer less data consistency, although several strategies have been employed to minimize it, as detailed in the topic of the research methods. Given that the interviews were conducted with people responsible for spaces or students positively engaged with MIT's entrepreneurial ecosystem, we have the risk of confirmation bias in which, perhaps, negative aspects were neglected. The time frame of the study-an immersion through a 1-month period-also presents risks of praised elements not proving themselves after a while, being this an opportunity for future longitudinal studies. Despite this, it is understood that the richness of the data collected, the quality of the interviews, and the complementary materials identified, as well as the way the data were processed and compiled, give the present study a strong reliability and opens new paths for studies in the practice of entrepreneurship education at universities.

\section{Endnotes}

${ }^{1}$ The fun environment is set as an escape valve in the face of pressure from studies at MIT. The main movement in this sense is called MIT Hacks, an insightful prank movement defined by the ethos-"Studying under the high-pressure conditions at MIT means students need creative outlets. Engaging in humorous and sometimes challenging pranks seems to be one such outlet."

${ }^{2}$ In the research, we perceived the phenomenon of innovation in informal environments. One of the answers, for example, pointed out that the first place he would go after having a startup idea would be the Muddy Charles Pub, a neighboring bar renowned by the concentration of inventors and scientists who use to help MIT's entrepreneurs.

\section{Additional file}

Additional file 1: Translation of the abstract into Arabic. (PDF $70 \mathrm{~kb}$ )

\section{Acknowledgements}

We thank Aaron (MITERS), Ariane Martins (VMS), Ben Rockney (TLO), Beth Kahn (TFP), Carol Campos, Deb Payson (IDC), Erin Martin (Martin Trust Center), Eswar Anandapadmanaban (Start Labs), Karen Golmer (Deshpande Center), Kevin Wiant (CIC), Laura Lopes (Boston University), Louis Kang (Media Lab), Lucas Cassiano (Media Lab), Morris Vanegas (CBA), Philippe Schlumpf (Ventureship Club), Rebecca Smith, Sher Vogel (D-Lab), and Tanya Abikoff (Sandbox Program). We also thank the 
spaces Area 51, Beaver Works, CIC, MakerWork, MIT Central Machine Shop, MIT Hobby Shop, Roxburry Innovation Center, District Hall, and Masschallenge for the openness and receptivity. In addition, we thank MIT as an institute for offering a welcoming atmosphere that permeates the environments and materializes in all of the anonymous MIT community members who helped us in small details or support during our immersion.

\section{Funding}

The present research did not count external funding bodies, being only financed by research resources of the University of São Paulo.

\section{Availability of data and materials}

Audio (interviews), studies, and photographic records can be found in the following link https://drive.google.com/ open?id=1_1704mcTQQQtT22b6qwxBqr9iPH3SgtB.

\section{Authors' contributions}

The first and second authors were in the immersion at MIT and led the interviews, as well as the local collection of complementary data. The third author supported, along the first authors, in the construction of theoretical background and data analysis. All authors read and approved the final manuscript.

\section{Competing interests}

The authors declare that they have no competing interests.

\section{Publisher's Note}

Springer Nature remains neutral with regard to jurisdictional claims in published maps and institutional affiliations.

\section{Author details}

${ }^{1}$ University of São Paulo, Av. Prof. Luciano Gualberto, 908, NPGT—Butantã, São Paulo, SP 05508-010, Brazil. University of São Paulo, Av. Professor Luciano Gualberto, 1289, Inovalab_-Prédio da Produção, Cidade Universitária, Butantã, São Paulo, SP 05508-010, Brazil.

Received: 27 November 2017 Accepted: 9 May 2018

Published online: 01 June 2018

\section{References}

Acs ZJ, Amorós JE (2008) Entrepreneurship and competitiveness dynamics in Latin America. Small Bus Econ 31(3):305-322

Acs ZJ, Desai S, Hessels J (2008) Entrepreneurship, economic development and institutions. Small Bus Econ 31(3):219-234 Aparicio S, Urbano D, Audretsch D (2016) Institutional factors, opportunity entrepreneurship and economic growth: panel data evidence. Technol Forecast Soc Chang 102:45-61

Aulet B (2013) Disciplined entrepreneurship: 24 steps to a successful startup. Wiley, Hoboken

Blenker P, Dreisler P, Færgemann HM, Kjeldsen J (2008) A framework for developing entrepreneurship education in a university context. Int J Entrep Small Bus 5(1):45-63

Blenker P, Dreisler P, \& Kjeldsen J (2006) Entrepreneurship education-the new challenge facing the universities. Department of management. Aarhus School of Business Working Paper, 2

Boyd RD, \& Apps JW (1980) Redefining the discipline of adult education. The AEA Handbook Series in Adult Education

Clark B (2004) Sustaining change in universities. McGraw-Hill Education (UK). Two Penn Plaza, New York

Coll C, \& Edwards D (Eds.) (1997) Teaching, learning and classroom discourse: approaches to the study of educational discourse. Fund. Infancia y Aprendizaje

Deakins D, Graham L, Sullivan R, Whittam G (1998) New venture support: an analysis of mentoring support for new and early stage entrepreneurs. J Small Bus Enterp Dev 5(2):151-161

Drucker PF (1985) Innovation and entrepreneurship practice and principles. Butterworth-Heinemann, USA

Eisenhardt KM (1989) Building theories from case study research. Acad Manag Rev 14(4):532-550

Etzkowitz H (2003) MIT and the rise of entrepreneurial science. Routledge, New York

Etzkowitz H (2013) StartX and the 'paradox of success': filling the gap in Stanford's entrepreneurial culture. Soc Sci Inf 52(4):605-627

Etzkowitz H, Leydesdorff L (2000) The dynamics of innovation: from national systems and "Mode 2" to a Triple Helix of university-industry-government relations. Res Policy 29(2):109-123

Fetters M, Greene PG, Rice MP, Butler JS (2010) The development of university-based entrepreneurship ecosystems: global practices. Edward Elgar Publishing, Cheltenham

Fritsch M (2008) How does new business formation affect regional development? Introduction to the special issue. Small Bus Econ 30(1):1-14

Gorman G, Hanlon D, King W (1997) Some research perspectives on entrepreneurship education, enterprise education and education for small business management: a ten-year literature review. Int Small Bus J 15(3):56-77

Guerrero M, Urbano D (2012) The development of an entrepreneurial university. J Technol Transf 37(1):43-74

Guerrero M, Urbano D (2014) Academics' start-up intentions and knowledge filters: an individual perspective of the knowledge spillover theory of entrepreneurship. Small Bus Econ 43(1):57-74

Guerrero M, Urbano D, Fayolle A (2016b) Entrepreneurial activity and regional competitiveness: evidence from European entrepreneurial universities. J Technol Transf 41:105-131

Guerrero M, Urbano D, Fayolle A, Klofsten M, Mian S (2016a) Entrepreneurial universities: emerging models in the new social and economic landscape. Small Bus Econ 47(3):551-563

Hayter CS, Lubynsky R, Maroulis S (2017) Who is the academic entrepreneur? The role of graduate students in the development of university spinoffs. J Technol Transf 42(6):1237-1254 
Heinonen J, Poikkijoki SA (2006) An entrepreneurial-directed approach to entrepreneurship education: mission impossible? J Manag Dev 25(1):80-94

Isenberg DJ (2010) How to start an entrepreneurial revolution. Harv Bus Rev 88(6):40-50. Retrieved from: https://hbr. org/2010/06/the-big-idea-how-to-start-an-entrepreneurial-revolution

Ito J (2014) Antidisciplinary. https://joi.ito.com/weblog/2014/10/02/antidisciplinar.html

Jansen S, van de Zande T, Brinkkemper S, Stam E, Varma V (2015) How education, stimulation, and incubation encourage student entrepreneurship: observations from MIT, IIIT, and Utrecht University. Int J Manag Educ 13(2):170-181

Katz JA (2003) The chronology and intellectual trajectory of American entrepreneurship education: 1876-1999. J Bus Ventur 18(2):283-300

Klofsten M (2000) Training entrepreneurship at universities: a Swedish case. J Eur Ind Train 24(6):337-344

Kolb AY, Kolb DA (2009) Experiential learning theory: a dynamic, holistic approach to management learning, education and development, The SAGE handbook of management learning, education and development, pp 42-68

Kolb DA (1984) Experiential learning. Englewood Cliffs

Kraiger K, Ford JK, Salas E (1993) Application of cognitive, skill-based, and affective theories of learning outcomes to new methods of training evaluation. J Appl Psychol 78(2):311

Kridel C (Ed.) (2010) Encyclopedia of curriculum studies (Vol. 1). Sage.

Kuratko DF (2005) The emergence of entrepreneurship education: development, trends, and challenges. Enterp Theory Pract 29(5):577-598

Lerner J (2010) The future of public efforts to boost entrepreneurship and venture capital. Small Bus Econ 35(3):255-264

Lüthje C, Franke N (2002) Fostering entrepreneurship through university education and training: lessons from Massachusetts Institute of Technology. In: European Academy of Management 2nd Annual Conference on Innovative Research in Management, Stockholm, May, pp 9-11

Mandrup M, Jensen TL (2017) Educational Action Research and Triple Helix principles in entrepreneurship education: introducing the EARTH design to explore individuals in Triple Helix collaboration. Triple Helix 4(1):5

Matheson R (2018) Startup aims to make vision care more accessible in developing world. MIT News Office - MIT News. Available at: http://news.mit.edu/2018/startup-plenoptika-vision-care-developing-world-0111. Accessed 20 Jan 2018

Neck HM, Greene PG (2011) Entrepreneurship education: known worlds and new frontiers. J Small Bus Manag 49(1):55-70 Newman DJ, Amir AR (2001) Innovative first year aerospace design course at MIT. J Eng Educ 90(3):375-381

O'Shea RP, Allen TJ, Morse KP, O'Gorman C, Roche F (2007) Delineating the anatomy of an entrepreneurial university: the Massachusetts Institute of Technology experience. R\&D Manag 37:1-16. https://doi.org/10.1111/j.1467-9310.2007.00454.x

Politis D (2005) The process of entrepreneurial learning: a conceptual framework. Entrep Theory Pract 29(4):399-424

Rasmussen E, Wright M (2015) How can universities facilitate academic spin-offs? An entrepreneurial competency perspective. J Technol Transf 40(5):782-799

Rasmussen EA, Sørheim R (2006) Action-based entrepreneurship education. Technovation 26(2):185-194

Roberts EB, Eesley CE (2011) Entrepreneurial impact: the role of MIT. Found Trends ${ }^{\circledR}$ Entrep 7:1-2), 1-149

Roberts EB, Murray F, \& Kim JD (2015) Entrepreneurship and innovation at MIT: continuing global growth and impact

Rothaermel FT, Agung SD, Jiang L (2007) University entrepreneurship: a taxonomy of the literature. Ind Corp Chang 16(4):691-791

Schumpeter JA (1942) Socialism, capitalism and democracy. Harper and Brothers

Stake RE (1978) The case study method in social inquiry. Educ Res 7(2):5-8

Steffensen M, Rogers EM, Speakman K (2000) Spin-offs from research centers at a research university. J Bus Ventur 15(1):93-111

St-Jean E, Audet J (2009) Factors leading to satisfaction in a mentoring scheme for novice entrepreneurs. Int J Evid Based Coach Mentoring 7(1):148-161

Sullivan R (2000) Entrepreneurial learning and mentoring. Int J Entrep Behav Res 6(3):160-175

\section{Submit your manuscript to a SpringerOpen ${ }^{\circ}$ journal and benefit from:}

- Convenient online submission

- Rigorous peer review

Open access: articles freely available online

- High visibility within the field

- Retaining the copyright to your article

Submit your next manuscript at $\gg$ springeropen.com 